\title{
Downwelling by Surface Gravity Waves?
}

\section{Kern E. Kenyon}

4632 North Lane, Del Mar, USA

Correspondence to: Kern E. Kenyon, kernken@aol.com

Keywords: Downwelling, Surface Gravity Waves

Received: April 26, $2017 \quad$ Accepted: May 24, $2017 \quad$ Published: May 27, 2017

Copyright $\odot 2017$ by authors and Scientific Research Publishing Inc.

This work is licensed under the Creative Commons Attribution International License (CC BY 4.0).

http://creativecommons.org/licenses/by/4.0/

\section{(c) (i) Open Access}

\section{ABSTRACT}

Based on observational evidence and the known physical characteristics of surface gravity waves, an argument is made that downwelling is not a significant feature over the life history of these waves under the usual conditions existing in the open oceans. Since it has recently been predicted that upwelling due to surface gravity waves should occur within a storm at sea, when the waves are growing in amplitude, the contrast is explained. As a result the importance of the upwelling concept due to waves in stimulating biological productivity is further emphasized, and the possibility for reducing global warming is worth repeating.

\section{INTRODUCTION}

A brief answer to the question posed in the title of the paper is an unqualified "no", at least for the life history of surface waves in the open oceans. However, oceanic upwelling by surface gravity waves is an entirely different story as outlined recently [1]. Such a glaring asymmetry is due mainly to the contrasting mechanisms by which surface waves are generated and dissipated in the environment.

\section{OPEN OCEAN}

Far away from land, within a wind storm, the amplitudes of surface gravity waves steadily grow larger in the wave propagation direction. Thus the orbits of the fluid particles grow larger in the same direction. Since all wave characteristics, including the particle motion, decrease with depth down from the surface, and essentially vanish at a depth comparable to a wave length, the forward particle motion at the tops (crests) of the orbits slightly exceeds in magnitude the backward motion at the bottoms (troughs) of the orbits. As a consequence there is a drift of mass in the wave propagation direction, well-known since the 1800 s as the Stokes drift. When the wave amplitudes grow, so does the Stokes drift increase in magnitude. Therefore, the Stokes drift is a divergent current requiring mass to be brought vertically up to the surface from below the depth of wave influence. In other words, upwelling is predicted to occur inside the storm region [1].

After the waves outrun the storm, or if the wind dies out above the waves, the waves will travel forth with the maximum amplitudes provided by the wind generation mechanism. Excluding other winds and 
ocean currents, there are really no other physical effects that can lead to changes in the wave amplitudes during propagation. Friction (even turbulent friction) is utterly negligible for typical swell. And waves measured at a station off southern California have been projected to have been created in a storm in the Indian Ocean half way around the world [2]. In conclusion, no downwelling (or upwelling) associated with surface gravity waves is expected to occur along the paths of propagation, be they as long as half the circumference of the earth.

A laboratory set-up can be envisioned in which surface waves are generated at one end of wave tank and knocked down by an opposing wind at the other end. Through decreasing the wave amplitude by the wind much faster than friction could do it, downwelling might be made visible using dye techniques.

\section{COASTAL REGION}

Very near a coast surface gravity waves, having traveled in from the open ocean, slow down, stop and are not reflected for the usually small beach slopes found at most coasts.

Downwelling by the waves in the surf zone is not prohibited by any principles, but it seems to be an unlikely situation. If downwelling does occur there, the region involved is just a thin strip parallel to the beach. Also shoaling waves bring mass to the beach through the Stokes drift, and the mass must be returned back to sea. Nature has found a horizontal method of solving this mass budget problem: rip currents. Exporting excess mass vertically downward would not be helpful when the ocean bottom is well up into the wave zone.

\section{DISCUSSION}

Upwelling by surface gravity waves has the potential to reduce global warming by the following chain of reasoning. For average swell produced in a wind storm the depth of wave influence, which is the origin for the upwelling, is below the light zone, where nutrient concentrations increase as plankton sink and dissolve. Thus the upwelling can bring nutrients back into the light zone stimulating phytoplankton blooming. Increasing phytoplankton abundance would cause the $\mathrm{CO}_{2}$ concentration in the water to go down. Then more atmospheric $\mathrm{CO}_{2}$ will diffuse into the ocean. Reducing atmospheric $\mathrm{CO}_{2}$ would tend to reduce global warming.

If downwelling by surface gravity waves in the ocean were just as frequent as upwelling, on the average there would be no net effect to ameliorate climate change. However, according to the above arguments that hypothetical scenario can be ruled out as being impossible under the assumptions stated, which are solidly based on observations. Thus the wave upwelling stands alone and has a better chance to be beneficial.

\section{CONCLUSION}

From generation to dissipation in the open ocean the prediction is put forward that there is no significant downwelling to be associated with propagating surface gravity waves. That is because typically no physical processes exist that are capable of sufficiently decreasing the wave amplitudes in the direction of wave propagation. Therefore, the Stokes drift of the waves never becomes a convergent current. On the other hand, upwelling has recently been suggested to occur during wave growth is a storm at sea, which potentially could lead to positive climatic changes.

\section{REFERENCES}

1. Kenyon, K.E. (2017) Upwelling by Surface Gravity Waves. Natural Science, 9, 133-135.

https://doi.org/10.4236/ns.2017.95013

2. Munk, W.H., Miller, G.R., Snodgrass, F.E. and Barber, N.F. (1963) Directional Recording of Swell from Distant Storms. Philosophical Transactions of the Royal Society London A, 255, 505-584.

https://doi.org/10.1098/rsta.1963.0011 
Submit or recommend next manuscript to SCIRP and we will provide best service for you:

Accepting pre-submission inquiries through Email, Facebook, LinkedIn, Twitter, etc. A wide selection of journals (inclusive of 9 subjects, more than 200 journals)

Providing 24-hour high-quality service

User-friendly online submission system

Fair and swift peer-review system

Efficient typesetting and proofreading procedure

Display of the result of downloads and visits, as well as the number of cited articles Maximum dissemination of your research work

Submit your manuscript at: http://papersubmission.scirp.org/

Or contact ns@scirp.org 